\title{
Spatiotemporal Distributions of Ocean Color Elements in Response to Tropical Cyclone: A Case Study of Typhoon Mangkhut (2018) Past over the Northern South China Sea
}

\author{
Junyi Li ${ }^{1,2}$, Quanan Zheng ${ }^{1,3}$, Min Li ${ }^{1,2}$, Qiang $\mathrm{Li}^{1}$ and Lingling Xie ${ }^{1,2, *}$ \\ 1 Laboratory of Coastal Ocean Variation and Disaster Prediction, College of Ocean and Meteorology, \\ Guangdong Ocean University, Zhanjiang 524088, China; jyl@gdou.edu.cn (J.L.); qzheng2@umd.edu (Q.Z.); \\ min_li@gdou.edu.cn (M.L.); liqiang@stu.gdou.edu.cn (Q.L.) \\ 2 Key Laboratory of Climate, Sources and Environments in Continent Shelf Sea and Deep Ocean, \\ Zhanjiang 524088, China \\ 3 Department of Atmospheric and Oceanic Science, University of Maryland, College Park, MD 20742, USA \\ * Correspondence: xiell@gdou.edu.cn
}

\section{check for} updates

Citation: Li, J.; Zheng, Q.; Li, M.; Li, Q.; Xie, L. Spatiotemporal Distributions of Ocean Color Elements in Response to Tropical Cyclone: A Case Study of Typhoon Mangkhut (2018) Past over the Northern South China Sea. Remote Sens. 2021, 13, 687. https://doi.org/ $10.3390 /$ rs13040687

Academic Editor:

Malgorzata Stramska

Received: 30 December 2020

Accepted: 6 February 2021

Published: 13 February 2021

Publisher's Note: MDPI stays neutral with regard to jurisdictional claims in published maps and institutional affiliations.

Copyright: (c) 2021 by the authors Licensee MDPI, Basel, Switzerland. This article is an open access article distributed under the terms and conditions of the Creative Commons Attribution (CC BY) license (https:// creativecommons.org/licenses/by/ $4.0 /)$.

\begin{abstract}
The ocean color elements refer to total suspended sediment (TSS) and chlorophyll-a (Chl-a), which are important parameters for the marine ecological environment. This study aims to examine the behavior of ocean color elements in response to a tropical cyclone in the case of typhoon Mangkhut (2018), which passed over the northern South China Sea (NSCS) on 16 September 2018, using satellite multi-sensor observations, Argo float profiles, and tidal gauge sea level data. The results indicate that typhoon Mangkhut (2018) resulted in TSS and Chl-a concentrations increasing, with the spatial and timing behavior different in the offshore, shelf, and basin areas. In the offshore area from the coast to isobath $50 \mathrm{~m}$, the mean TSS concentration, i.e., $C_{\mathrm{TSS}}$, reached $13.9 \mathrm{mg} / \mathrm{L}$ on 18 September 2018, two days after typhoon landfall, against about $3.5 \mathrm{mg} / \mathrm{L}$ before typhoon landfall. In the shelf area with depths from $50 \mathrm{~m}$ to $100 \mathrm{~m}$, the mean $C_{\mathrm{TSS}}$ reached $2.5 \mathrm{mg} / \mathrm{L}$, against about $0.8 \mathrm{mg} / \mathrm{L}$ before typhoon landfall. In the basin area with depths of $100 \mathrm{~m}$ and beyond, the mean $C_{\mathrm{TSS}}$ had only a little fluctuation. On the other hand, in the offshore area, the mean Chl-a concentration, i.e., $C_{\text {Chl-a, }}$, was $7.3 \mathrm{mg} / \mathrm{m}^{3}$ on 21 September, five days after typhoon landfall, against $2.4 \mathrm{mg} / \mathrm{m}^{3}$ as the monthly mean value. Furthermore, TSS concentrations favorable for Chl-a bloom range from 6 to $7 \mathrm{mg} / \mathrm{L}$ in this area. In the shelf area, the mean $C_{\mathrm{Chl}-\mathrm{a}}$ increased from $0.2 \mathrm{mg} / \mathrm{m}^{3}$ to $0.6 \mathrm{mg} / \mathrm{m}^{3}$ in two days. In the basin area, the $C_{C h l-a}$ increased from $0.1 \mathrm{mg} / \mathrm{m}^{3}$ to $0.2 \mathrm{mg} / \mathrm{m}^{3}$ during typhoon passage. Concurrent dynamic condition analysis results indicate that, in the offshore area, typhoon-induced solitary continental waves may play a dominant role in determining the spatial distribution features of the TSS originating from the Pearl River runoff. The Chl-a bloom delayed rather than concurrently occurred with the terrigenous nutrient peak, which is attributed to the nonlinear relation between

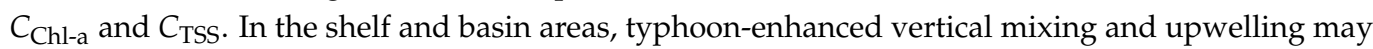
play dominant roles in determining the spatiotemporal behavior of the TSS and the Chl-a.
\end{abstract}

Keywords: typhoon Mangkhut (2018); Northern South China Sea; resuspended sediment; Chla bloom

\section{Introduction}

As typhoons pass over the ocean, tremendous wind force strongly impacts the upper ocean. This process must first enhance ocean vertical mixing and upwelling [1-3]. Meanwhile, the typhoon-induced upwelling and dynamic processes of the eddy adjustment are able to enhance the preexisting cyclonic eddy [4]. On the continental shelf, strong winds and heavy rainfall that accompany the arrival of a typhoon directly affect the hydrodynamic environment. The river runoff caused by heavy rainfall raises transporting fresh water and terrestrial materials into the ocean. The winds cause high waves and increase the 
near-bottom currents, which resuspends the sediment on the sea floor [5]. The suspended sediment is transported to the outer shelf with the current [6]. The coastal storm surges event due to the passing typhoon generates continental shelf waves and Kelvin waves [7,8]. The wave could be amplified as the storm moves nearly parallel to the shelf, which would be over the dam. The terrestrial material would be transported to the ocean with the seawater. Weber [9] pointed out that the mean alongshore velocity associated with these waves is typically $1 \mathrm{~cm} / \mathrm{s}$, and the non-linear mean transport may be important for the transport of biological material. Furthermore, the particulate matter from land, together with sea salt aerosol from breaking waves during whitecap formation, should be injected into the shelf area with the rainfall when wind speed is significant [10-12]. These processes would increase the concentration of the suspended sediment in the ocean.

The South China Sea (SCS) is a hallway of Pacific Ocean typhoons and a local typhoon birthplace. There is an average of 6.0 typhoons a year that pass over the SCS, and among them, 1.3 originate locally [13]. Shang et al. [14] investigated a Chl-a bloom induced by typhoons in the SCS, and found that typhoon Lingling (2001) induced a large patch of enhanced Chl-a concentration of $0.37 \mathrm{mg} / \mathrm{m}^{3}$ against the background level of $0.08 \mathrm{mg} / \mathrm{m}^{3}$. Chen et al. [3] investigated the ocean biological and physical responses to typhoon Megi and found that a Chl-a bloom was triggered by strong vertical mixing and upwelling. Pan et al. [2] found that the Chl-a blooms during a typhoon event may be attributed to multiple factors related to the ocean dynamic conditions and cyclone characteristics.

Satellite remote sensing observations are a powerful data source for investigating characteristics and mechanisms of ocean color element response to typhoons. In particular, the Soil Moisture Active Passive (SMAP) sensor provides the sea surface salinity (SSS) distribution data, which contain information about the river runoff spreading on the continental shelf.

This case study aims to reveal the ocean color element responses to the passage of typhoon Mangkhut (2018) over the NSCS in September 2018, based on satellite multi-sensor observations, Argo float profile data, and tidal gauge sea level data. This paper is organized as follows. The next section gives a brief introduction to the data and methodology, including algorithms for the retrieval of the Chl-a and the total suspended sediment (TSS) concentrations from satellite observations. Section 3 analyzes the spatiotemporal distribution feature of the TSS and the Chl-a in the NSCS during the typhoon Mangkhut (2018) passage. Section 4 analyzes the behavior of Chl-a blooms in three subareas: the offshore, shelf, and basin areas. Section 5 contains a summary.

\section{Data and Methodology}

\subsection{Study Area}

The SCS is the largest semi-enclosed marginal sea of the northwest Pacific Ocean. The area of the continental shelf and island occupies $48 \%$ of the total area [15]. In the NSCS, the width of the continental shelf, with depths shallower than $200 \mathrm{~m}$ extending from the coast, is about $200 \mathrm{~km}$. The depth contour is generally parallel to the coastline. The Pearl River contributes the biggest runoff for this shelf. The study area occupies an area with boundary lines on two sides about $200 \mathrm{~km}$ to the typhoon track. According to the geological features of the shelf and traditional Chl-a distribution, the study area is divided into three subareas: the offshore, shelf, and basin areas, as shown in Figure 1. The depths of the offshore area are shallower than $50 \mathrm{~m}$. The shelf area is located on the continental shelf shallower than $100 \mathrm{~m}$. The basin area extends from an isobath of $100 \mathrm{~m}$ to the SCS deep basin, with depths near $3000 \mathrm{~m}$. The average distance from the shelf and basin area to the coastline are $70 \mathrm{~km}$ and $140 \mathrm{~km}$, respectively.

\subsection{Typhoon Mangkhut (2018)}

Super typhoon Mangkhut (2018) formed in the central Pacific Ocean as a tropical depression at 11:00 UTC on 7 September 2018. It rapidly strengthened into a typhoon, and moved westward to the SCS, as shown in Figure 1. The size of typhoon Mangkhut 
(2018) was larger than $1000 \mathrm{~km}$, and it sustained wind speeds above $65 \mathrm{~m} / \mathrm{s}$ for a maximum of $2 \mathrm{~min}$. The minimum central pressure was less than $910 \mathrm{hPa}$. It landed on the south coast of China with a wind speed higher than $48 \mathrm{~m} / \mathrm{s}$ by 9:00 UTC on 16 September 2018 . Typhoon Mangkhut (2018), the strongest typhoon that landed on China in 2018, brought heavy rainfall of $389 \mathrm{~mm}$ and a high storm surge water level of $2 \mathrm{~m}$. The storm surge superposed on the high waves, pushed by a strong wind that caused enormous damage to the properties along the coast of China.

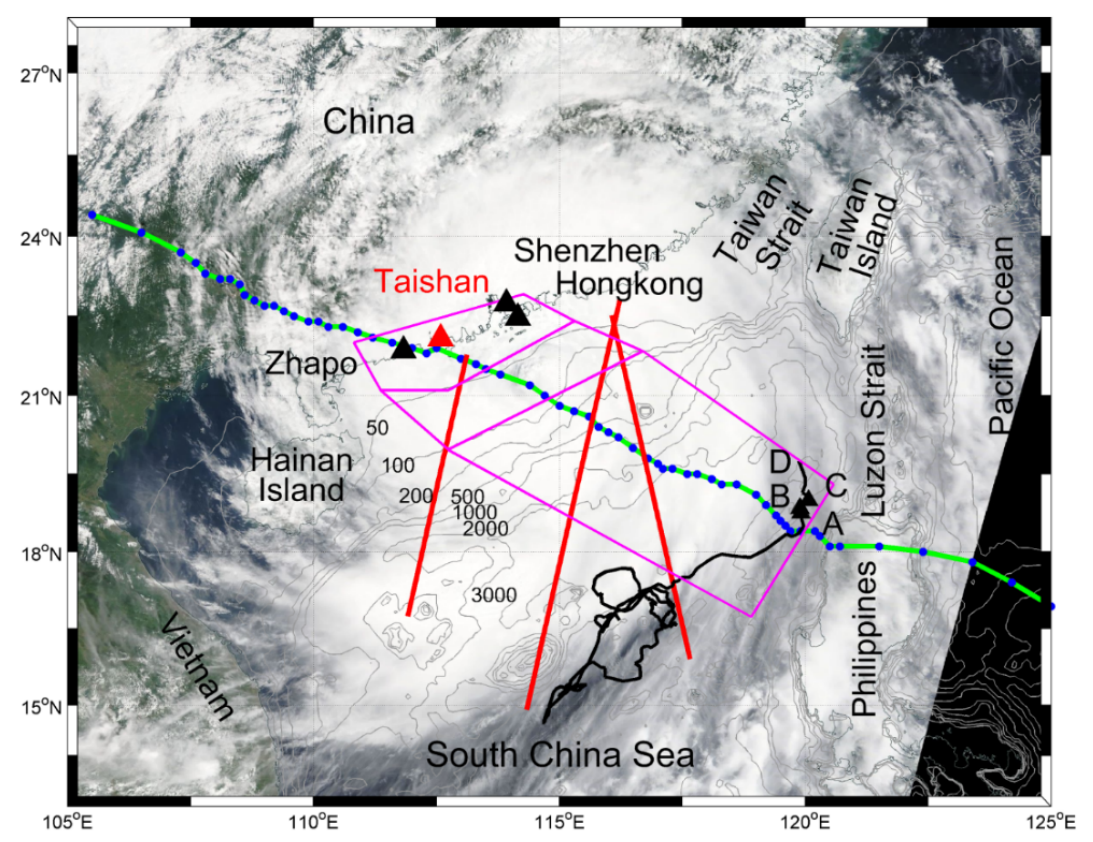

Figure 1. MODIS visible band image of typhoon Mangkhut (2018) at 3:10 UTC on 16 September 2018. Green curve with blue dots (every $3 \mathrm{~h}$ ) represents the typhoon track. Red lines represent concurrent satellite altimeter tracks. Pink polygons represent the study area consisting of three subareas: the offshore, shelf, and basin areas. Black triangles along the coastline represent tidal gauge stations Zhapo, Hongkong, and Shenzhen. The red triangle represents the landfall point of the typhoon center in Taishan, Guangdong, China. Black curves show trajectories of the Argo floats, and black triangles A, B, C, and D represent the float locations on 9, 13, 17, and 21 September 2018, respectively. Numerals on the isobaths are in $\mathrm{m}$.

The track of typhoon Mangkhut (2018) was obtained from the Tropical Cyclone Data Center of the China Meteorological Administration (CMA) (http:/ / tcdata.typhoon.org. $\mathrm{cn}$ ) [16]. The data of typhoon center locations, minimum pressure, and two-minute mean maximum sustained wind near the tropical cyclone center were gathered every $6 \mathrm{~h}$ and $3 \mathrm{~h}$ after it entered the SCS.

\subsection{Satellite Multi-Sensor Data}

The Chl-a concentration data from 1 to 30 September 2018 are downloaded from http:/ / oceandata.sci.gsfc.nasa.gov/. The dataset is a level two product, with a spatial resolution of $1 \mathrm{~km}$ derived from an empirical algorithm and the ocean color index (OCI) for Terra and Aqua MODIS sensors [17]. The data from the two platforms are merged for improving the coverage of the Chl-a data [18]. In this study, the average Chl-a concentration is calculated by the following algorithm [19]:

$$
C_{\text {chl-a }}=\frac{C_{\text {chl-aTerra }}+C_{\text {chl-aAqua }}}{2}
$$

where $C_{\text {chl-aTerra }}$ and $C_{\text {chl-aAqua }}$ are the Chl-a concentration data derived from the Terra and Aqua observations, respectively. The monthly mean chlorophyll-a concentration from 2002 
to 2016 , with a spatial resolution of $5 \mathrm{~km}$, is also used to calculate the mean state of the chlorophyll-a in the SCS.

The remote sensing reflectance $(R r s)$ at 443,488, 555, and $645 \mathrm{~nm}$ with a spatial resolution of $1 \mathrm{~km}$ was obtained from the NASA Ocean Biology Processing Group, which could be used to calculate the TSS concentration.

The sea surface temperature (SST) data from 1 to 26 September 2018 are downloaded from https://podaac-opendap.jpl.nasa.gov/. The dataset is a level two product from Advanced Microwave Scanning Radiometer-2 (AMSR-2) on board the Global Change Observation Mission-W1 (GCOM-W1). The temporal resolutions of AMSR-2 at a frequency of $6.9 \mathrm{GHz}$ are once every two days, and the spatial resolution is $25 \mathrm{~km}$ [20]. Since the microwave has a certain penetration performance through cloud cover, the data have advantages for ocean observation, particularly during typhoon passage.

The sea surface wind data containing measurements of the wind direction and wind speed at $10 \mathrm{~m}$ above the sea surface are obtained from http:/ / oceandata.sci.gsfc.nasa. gov /. The data are derived from level two processing of scatterometer data with a spatial resolution of $25 \mathrm{~km}$, measured by the Advanced Scatterometer (ASCAT) instrument on EUMETSAT Metop-A satellite.

The level two SSS observations of the SCS in September 2018 derived from the soil moisture active passive (SMAP) mission are downloaded from http: / / oceandata.sci.gsfc. nasa.gov / [21]. The SMAP dataset is a gridded product with a temporal resolution of eight days and a horizontal resolution of $40 \mathrm{~km}$.

The along-track significant wave height (SWH) is produced and distributed by the Copernicus Marine Environment Monitoring Service (CMEMS), using altimeter alongtrack data of Sentinel 3a and Saral-AltiKa, with repeat ground tracks every $4 \mathrm{~d}$ and $35 \mathrm{~d}$, respectively [22]. The temporal resolution is $1 \mathrm{~s}$, and the spatial resolution is about $7 \mathrm{~km}$ in the study area. The eight-point moving average is applied to the data to filter out ocean processes with a length scale less than $50 \mathrm{~km}$. Sentinel 3a passed over the study area twice at 2:29 UTC on 16 September and at 13:59 UTC on 19 September 2018, respectively. Saral-AltiKa passed over once at 10:39 UTC on 17 September.

The Argo float profile data were obtained by the Argo float (ID 2901481) that was deployed at $16.67^{\circ} \mathrm{N}, 116.22^{\circ} \mathrm{E}$ on 28 April 2016. The float is designed to measure the temperature and salinity profiles from about $5 \mathrm{~m}$ to $1200 \mathrm{~m}$ every four days. The float drifted to the northwest of the Philippines on 13 September 2018 before the typhoon arrived. Another profile was obtained on 17 September, one day after the typhoon passed by.

\subsection{TSS Retrivial}

Previous studies have developed various algorithms for estimating the water quality, as shown in Table 1 [23-26]. One can see that the TSS concentration can be calculated with retrieval algorithms using $\operatorname{Rrs}(443), \operatorname{Rrs}(488), \operatorname{Rrs}(555)$, and $\operatorname{Rrs}(645)$ data. These algorithms are applied to the data of $\operatorname{Rrs}$ (645) distribution on 20 September 2018, as shown in Figure 2.

Table 1. TSS concentration $\left(C_{\mathrm{TSS}}\right)$ retrieval models.

\begin{tabular}{|c|c|c|}
\hline Order & Algorithm & Model \\
\hline 1 & $C_{\mathrm{TSS}}=-1.91+1140.25 \times \operatorname{Rrs} 645$ & Miller \\
\hline 2 & $C_{\mathrm{TSS}}=0.6455+1455.7 \times \operatorname{Rrs} 645$ & Miller (adjusted) \\
\hline 3 & $\lg C_{\mathrm{TSS}}=0.6311+22.2158 \times(\operatorname{Rrs} 555+\operatorname{Rrs} 645)-0.5239 \times(\operatorname{Rrs} 488 / \operatorname{Rrs} 555)$ & Zhang \\
\hline 4 & $\lg C_{\mathrm{TSS}}=2.4618+0.9905 \times \lg (\operatorname{Rrs555}+\operatorname{Rrs645})-1.2073 \times \lg (\operatorname{Rrs} 488 / R r s 555)$ & Tassan \\
\hline 5 & $C_{\mathrm{TSS}}=3.2602 \times(\operatorname{Rrs} 443 / \operatorname{Rrs} 555)^{-3.9322}$ & Pan \\
\hline
\end{tabular}

Figure 3 shows the average TSS concentration for the offshore, shelf, and ocean area using five retrieval models on 20 September 2018. One can see that the average TSS concentrations in the shelf area derived from five algorithms are similar (green curve). In the offshore area, the average TSS concentration (red curve) is about $3 \sim 7 \mathrm{mg} / \mathrm{L}$ from the 
first four models, and $24 \mathrm{mg} / \mathrm{L}$ from the fifth algorithm. Thus, the results from the first four algorithms should have more statistical weight. In the ocean area, the algorithms could be divided into three categories according to the average TSS concentrations: (1) a high concentration model, i.e., the first two models, (2) a moderate concentration model, i.e., the third and fourth models, and (3) a low concentration model, i.e., the last model. $\mathrm{Li}$ et al. [12] found that the suspended sediment concentration in the deep sea basin of the SCS increases from 0.48 to $1.4 \mathrm{mg} / \mathrm{L}$ during a typhoon passage. Moreover, the observed TSS concentration from our cruise investigation in August 2020 in the north of the SCS is $\sim 0.8 \mathrm{mg} / \mathrm{L}$. Moreover, it is obviously unreasonable that model 1 gives negative values of TSS concentration for the small values of Rrs (645). Thus, we used model 2 to calculate the TSS concentration in the study case [24].

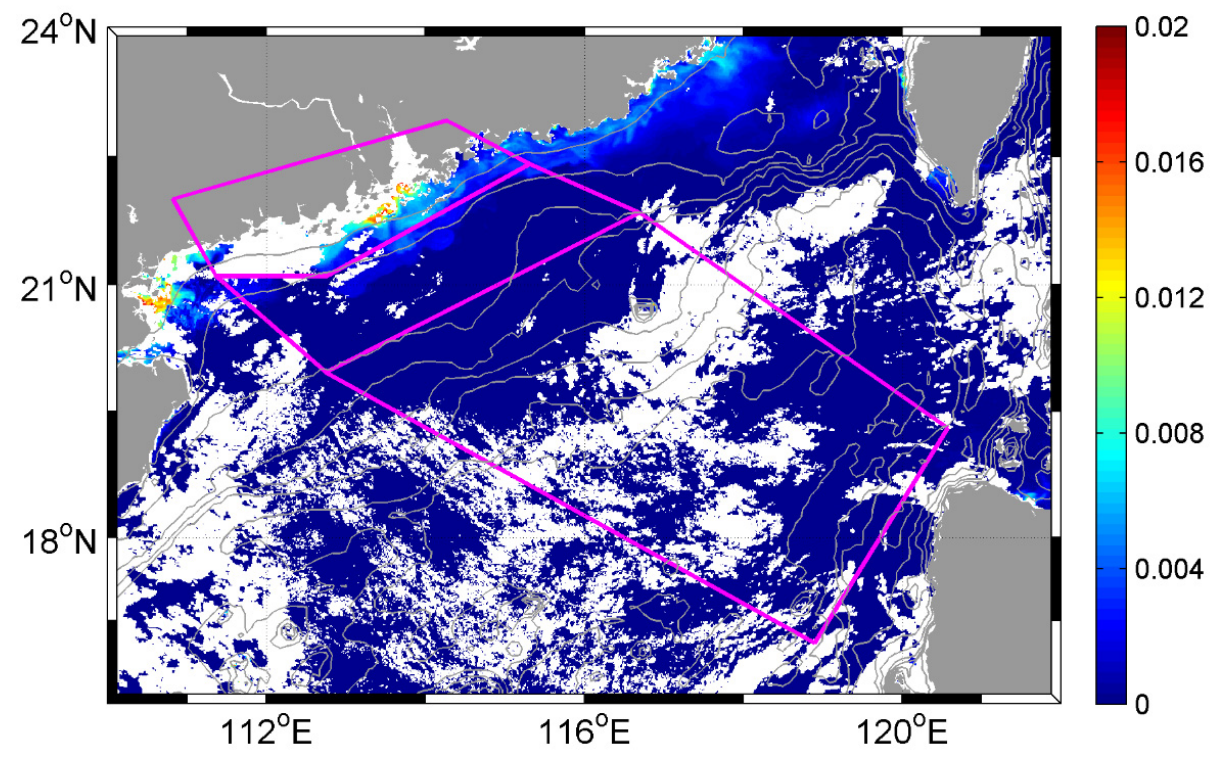

Figure 2. $\operatorname{Rrs}(645)\left(\mathrm{sr}^{-1}\right)$ derived from MODIS images on 20 September 2018. Pink polygons represent the study area consisting of three subareas: the offshore, shelf, and basin areas.

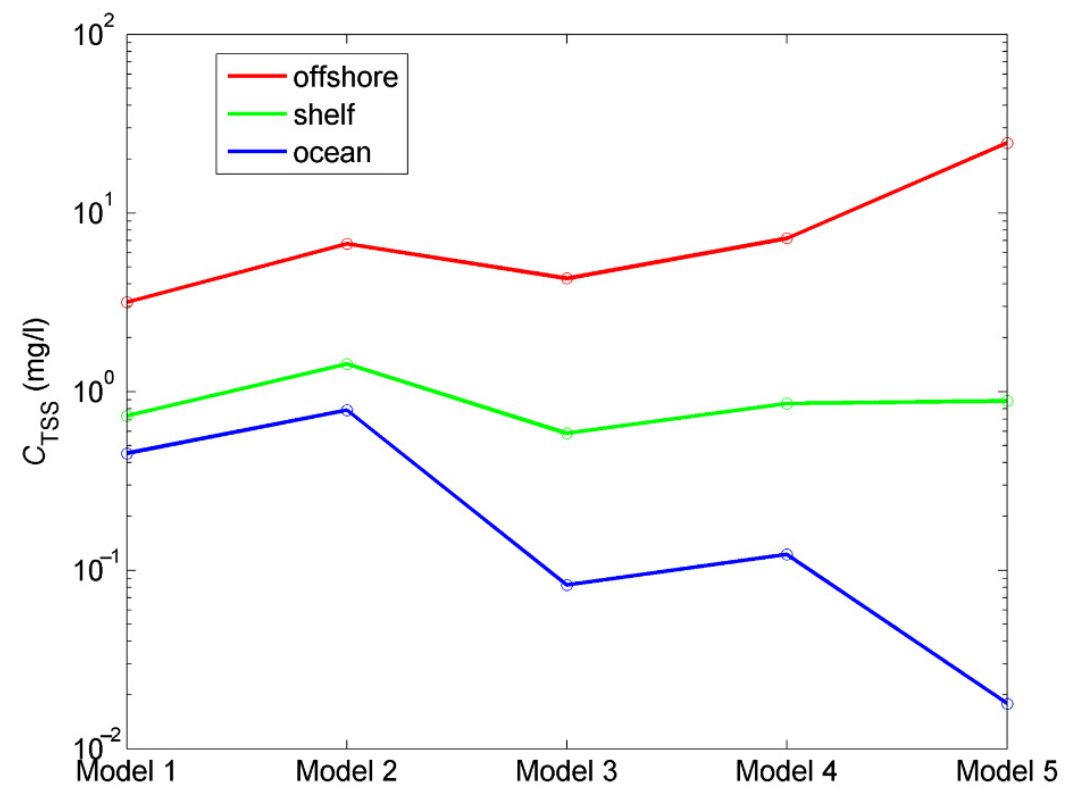

Figure 3. Average TSS concentration using five retrieval models for offshore, shelf, and ocean areas on 20 September 2018. 


\subsection{Tidal Gauge Data}

The de-tided sea level data measured at tidal gauge stations Shenzhen, Hong Kong, and Zhapo from 1 to 25 September 2018 were used to calculate the sea level anomaly (SLA) with respect to a 25-day mean sea level. The temporal resolution is $1 \mathrm{~h}$.

\subsection{Ekman Pumping}

The concurrently strong winds produce an Ekman transport in the ocean surface layer, which leads to an Ekman pumping. The velocity of upwelling is calculated by the following equations [27]:

$$
W e=\frac{1}{\rho f}(\nabla \times \tau),
$$

where We is the velocity of Ekman pumping and $\rho, f$, and $\tau$ are the seawater density, Coriolis parameter, and wind stress, respectively.

The wind stress curl is:

$$
\nabla \times \tau=\frac{1}{R \cos \varphi}\left(\frac{\partial \tau_{y}}{\partial \lambda}-\frac{\partial}{\partial \varphi}\left(\tau_{x} \cos \varphi\right)\right),
$$

where $R$ is the earth radius, $\varphi$ and $\lambda$ are the geographic latitude and longitude, respectively, and $\tau_{x}$ and $\tau_{y}$ are the zonal and meridional wind stress, respectively. In order to calculate the wind stress curl, a finite difference scheme is applied [3]:

$$
\nabla \times \tau_{i, j}=\frac{1}{R \cos \varphi_{i, j}}\left(\frac{\left(\tau_{y}\right)_{i+1, j}-\left(\tau_{y}\right)_{i-1, j}}{2 \Delta \lambda}-\frac{\left(\tau_{x} \cos \varphi\right)_{i, j+1}-\left(\tau_{x} \cos \varphi\right)_{i, j-1}}{2 \Delta \varphi}\right),
$$

The wind stress curl is [28]:

$$
\tau=\rho_{a} C_{D} U|U|,
$$

where $\rho_{a}, C_{D}$, and $U$ are the air density, drag coefficient, and $10 \mathrm{~m}$ wind, respectively.

\section{Spatial Distribution Analysis}

The TSS and Chl-a time series images during the typhoon Mangkhut (2018) passage are shown in Figure 4. From Figure 4a, one can see that on 15 September 2018, one day before typhoon landfall, the high TSS values in the offshore area were concentrated in the Pearl River Estuary. The mean value was about $3.5 \mathrm{mg} / \mathrm{L}$ with the maximum of $15.0 \mathrm{mg} / \mathrm{L}$. This means that the rushing river water is the primary source of suspended sediment. The TSS concentration in the shelf area was $0.9 \mathrm{mg} / \mathrm{L}$, much lower than that in the estuary. The TSS data in the basin area were missing due to the heavy clouds.

Figure $4 \mathrm{~b}$ shows the distribution of TSS on 18 September 2018, two days after typhoon landfall. A high-concentration TSS plume was distributed from the Pearl River Estuary to the offshore water with depths of about $70 \mathrm{~m}$. The maximum TSS concentration of about $40.0 \mathrm{mg} / \mathrm{L}$ was distributed near the Hong Kong coast, located inside the Pearl River Estuary. The mean TSS concentration in the offshore area was higher than $13.9 \mathrm{mg} / \mathrm{L}$, against $3.5 \mathrm{mg} / \mathrm{L}$ on 15 September before typhoon landfall. Meanwhile, the distribution extent of high TSS concentration was remarkably expanded to the southwest of the Pearl River Estuary. In the shelf area, the mean TSS concentration increased by three times, reaching $2.5 \mathrm{mg} / \mathrm{L}$. Furthermore, one can see a high TSS plume with a concentration higher than $15 \mathrm{mg} / \mathrm{L}$, five times higher than that before typhoon landfall. In the basin area, however, the mean TSS concentration increased only a little.

The TSS was deposited slowly after typhoon landfall, as shown in Figure $4 \mathrm{c}$,d. In the offshore area, the mean TSS concentration decreased slowly from $6.7 \mathrm{mg} / \mathrm{L}$ on 20 September (Figure 4c) to $6.3 \mathrm{mg} / \mathrm{L}$ on 21 September (Figure $4 \mathrm{~d}$ ). In the shelf and basin areas, it remained at 0.8 and $0.9 \mathrm{mg} / \mathrm{L}$ on 20 and 21 September, respectively.

Figure $4 \mathrm{e}$ shows the distribution image of Chl-a on 15 September. One can see that, in the offshore area, the Chl-a concentration of about $15 \mathrm{mg} / \mathrm{m}^{3}$ was distributed in the 
estuary and along the coast. In the shelf area, it decreased to about $0.5 \mathrm{mg} / \mathrm{m}^{3}$. In the basin area, it further decreased to less than $0.3 \mathrm{mg} / \mathrm{m}^{3}$.
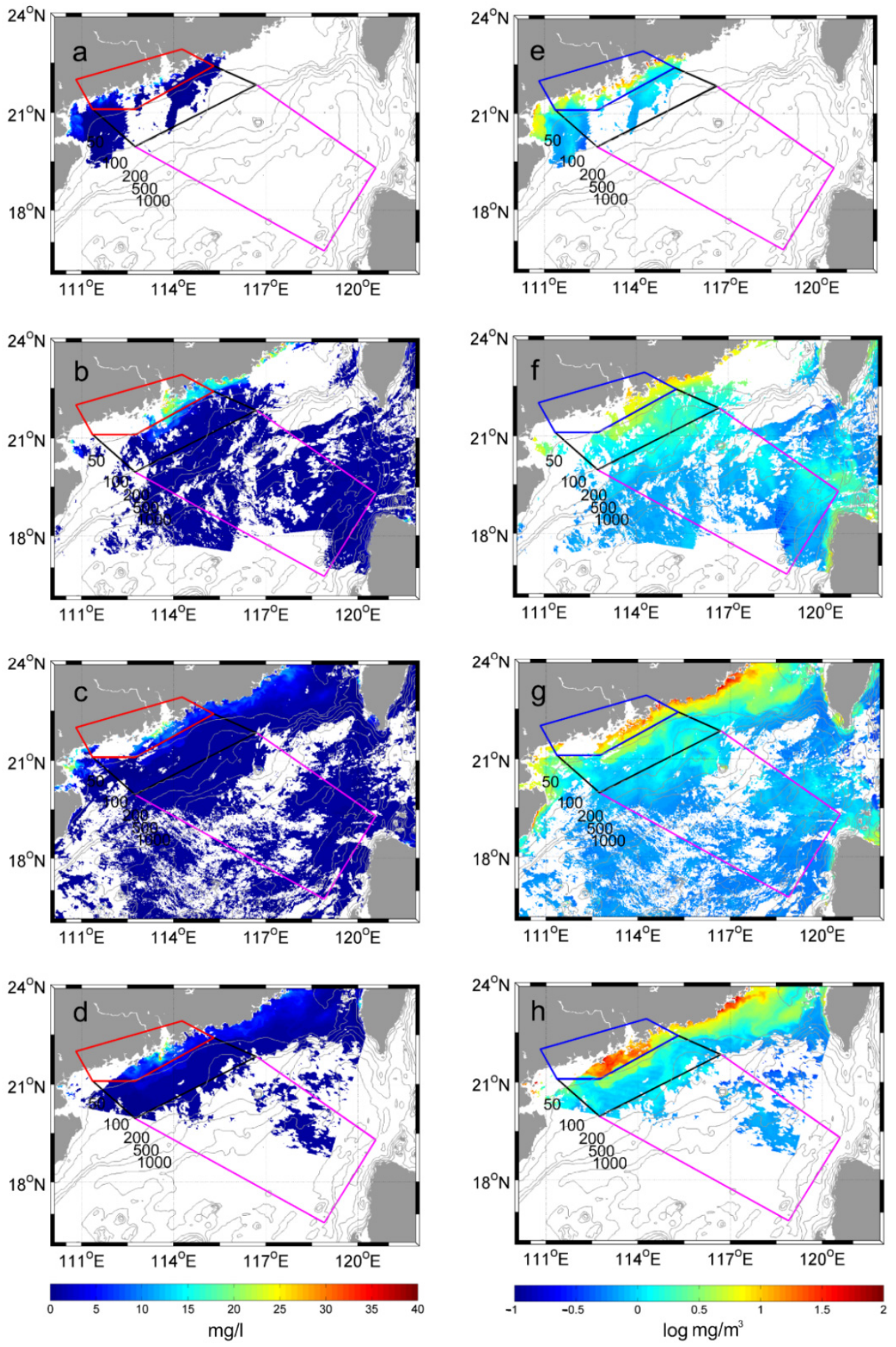

Figure 4. Time series images of (a-d) TSS concentration and (e-h) Chl-a concentration in the NSCS on 15, 18, 20, and 21 September 2018. Three polygons from the coast to the deep basin are defined as the offshore, shelf, and basin areas, respectively. Color codes for TSS concentration and Chl-a concentration (logarithmic scale) are in $\mathrm{mg} / \mathrm{L}$ and $\mathrm{mg} / \mathrm{m}^{3}$, respectively. Numerals on isobaths are in $\mathrm{m}$.

Figure $4 \mathrm{f}$ shows the $\mathrm{Chl}-\mathrm{a}$ concentration distribution on 18 September. One can see that, in the offshore area, the mean Chl-a concentration was $3 \mathrm{mg} / \mathrm{m}^{3}$, against $15 \mathrm{mg} / \mathrm{m}^{3}$ on 15 September. On the other hand, in the shelf area, the Chl-a concentration was double 
that on September 15. Meanwhile, in the basin area, the Chl-a also bloomed, with a peaked concentration of $1.4 \mathrm{mg} / \mathrm{m}^{3}$.

From Figure 4g,h, one can see that, in the offshore area, the Chl-a bloom delayed to 20 and 21 September. The maximum Chl-a concentration reached as high as $40 \mathrm{mg} / \mathrm{m}^{3}$ on 21 September, against $15 \mathrm{mg} / \mathrm{m}^{3}$ before typhoon landfall.

The time series of TSS concentrations are shown as red curves in Figure 5. From Figure $5 \mathrm{a}$, one can see that, in the offshore area, the mean TSS concentration (red curve) remained lower than $6 \mathrm{mg} / \mathrm{L}$ before 15 September and peaked up to $13.9 \mathrm{mg} / \mathrm{L}$ on 18 September, then reduced quickly to $2.9 \mathrm{mg} / \mathrm{L}$ on 23 September. In the shelf area, it remained lower than $1 \mathrm{mg} / \mathrm{L}$ before 15 September, peaked up to $2.5 \mathrm{mg} / \mathrm{L}$ on 18 September, and decreased to $1.0 \mathrm{mg} / \mathrm{L}$ on 22 September, as shown in Figure 5b. The high standard deviations (SDVs) of TSS values in the offshore and shelf areas were greater than 10 and $1 \mathrm{mg} / \mathrm{L}$ from 18 to 22 September, indicating that the TSS concentration fluctuated considerably. In the basin area, the mean TSS concentration only had a little fluctuation, especially during the typhoon passage, as shown in Figure 5c.

The time series of mean Chl-a concentrations are shown as blue curves in Figure 5. From Figure 5a, one can see that, in the offshore area, the mean Chl-a concentration was lower than $5 \mathrm{mg} / \mathrm{m}^{3}$ before 15 September. It sharply increased from $3.2 \mathrm{mg} / \mathrm{m}^{3}$ on 18 September to $7.3 \mathrm{mg} / \mathrm{m}^{3}$ on 21 September, then sharply decreased to $2.5 \mathrm{mg} / \mathrm{m}^{3}$ within two days. Figure $5 \mathrm{~b}$ shows that, in the shelf area, the mean $\mathrm{Chl}-\mathrm{a}$ concentration increased from $0.2 \mathrm{mg} / \mathrm{m}^{3}$ before typhoon landfall to $0.6 \mathrm{mg} / \mathrm{m}^{3}$ after typhoon landfall. Figure $5 \mathrm{c}$ shows that, in the basin area, the mean Chl-a concentration increased from $0.1 \mathrm{mg} / \mathrm{m}^{3}$ to $0.2 \mathrm{mg} / \mathrm{m}^{3}$ during typhoon passage.
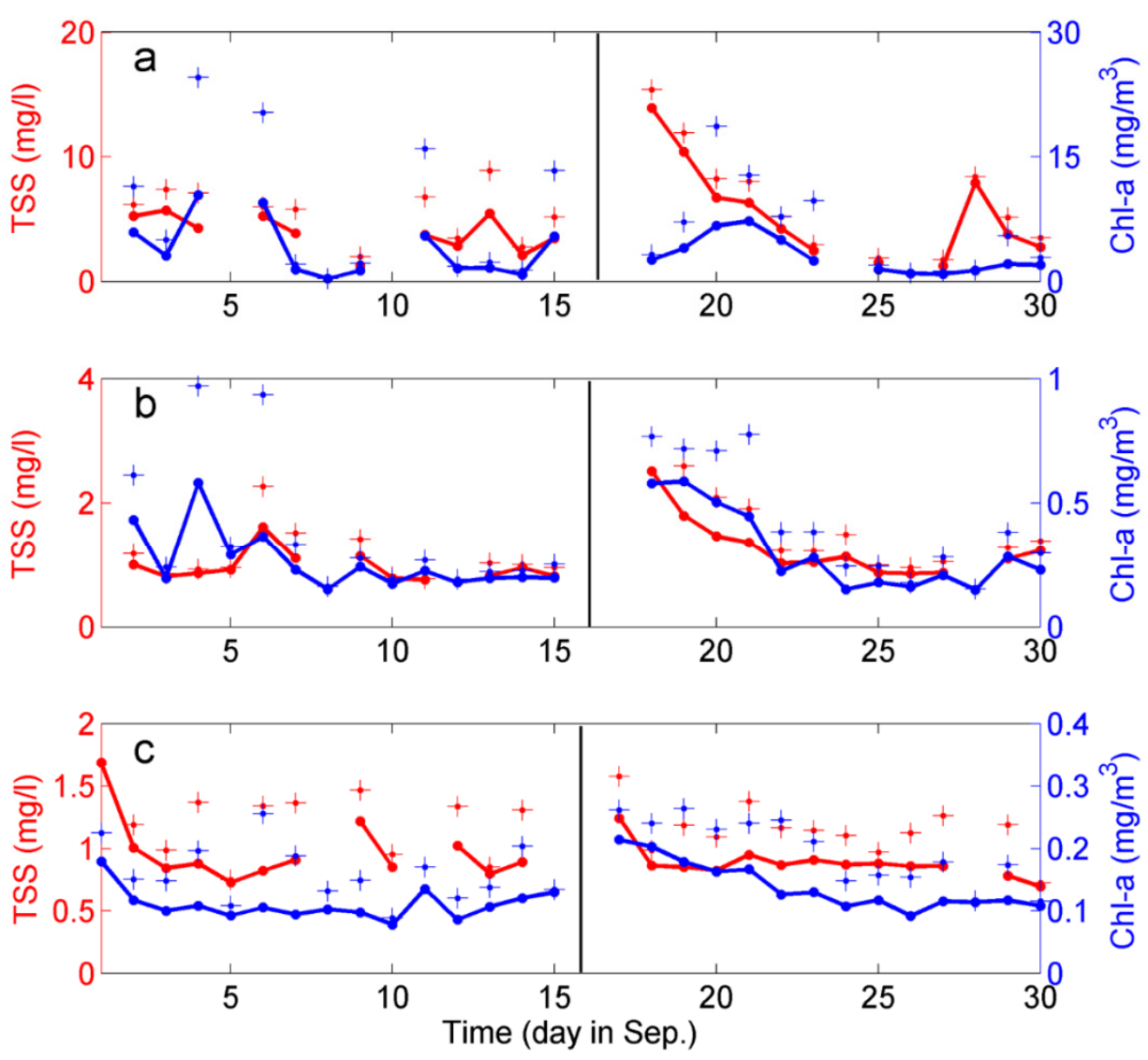

Figure 5. Time series of TSS and Chl-a concentrations for (a) the offshore, (b) shelf, and (c) basin areas in September 2018. Red and blue curves with dots and plus signs represent the mean and the SDV of TSS and Chl-a concentrations, respectively. Black vertical lines represent passing times of typhoon Mangkhut (2018). 
The above time series analysis indicates that the Chl-a blooms in the offshore and shelf areas lagged by four to five days behind the TSS peak. As shown in Figure 5a,b, the TSS concentration peaked on 18 September, two days after typhoon landfall. On the other hand, the Chl-a concentration in the offshore area peaked on 20 September, and, in the shelf area, peaked on 21 September, i.e., the Chl-a blooms had delayed for four and five days, respectively.

\section{Chl-a Bloom Timing Analysis}

As shown in Figure 5, the Chl-a blooms in three subareas were not concurrently occurring. In this section, the mechanisms to cause Chl-a bloom timing are analyzed using multi-sensor data.

\subsection{Offshore Area}

Figure $6 \mathrm{a}-\mathrm{d}$ shows the time series images of the SSS distribution in the NSCS from 10 to 21 September 2018. From Figure 6a, one can see that on 10 September, before typhoon arrival, a low salinity water plume with an SSS lower than 30 and a length of about $150 \mathrm{~km}$ was distributed in the west of the Pearl River Mouth. Figure $6 \mathrm{~b}$ shows that on 17 September, after typhoon landfall, the low SSS water plume disappeared, and instead, the major study area was occupied by high SSS water, with a salinity of 34-35. On 18 September, the SSS recovered to the level of that before typhoon landfall, as shown in Figure 6c. Figure 6d shows that on 21 September, five days after typhoon landfall, the low SSS water plume reappeared in the offshore area. It expanded to about $300 \mathrm{~km}$ and spread southwestward along the coast, which resulted in heavy rainfall of $389 \mathrm{~mm}$, with the maximum hourly rainfall intensity reaching $74 \mathrm{~mm}$ along the coast of Guangdong during the typhoon Mangkhut (2018) passage [29]. The river discharges of fresh water and terrigenous nutrients should be favorable to phytoplankton blooms [30]. In addition, the typhoon-induced local vertical mixing and upwelling could provide extra vertical nutrient transport to further enhance the ocean primary productivity [31].
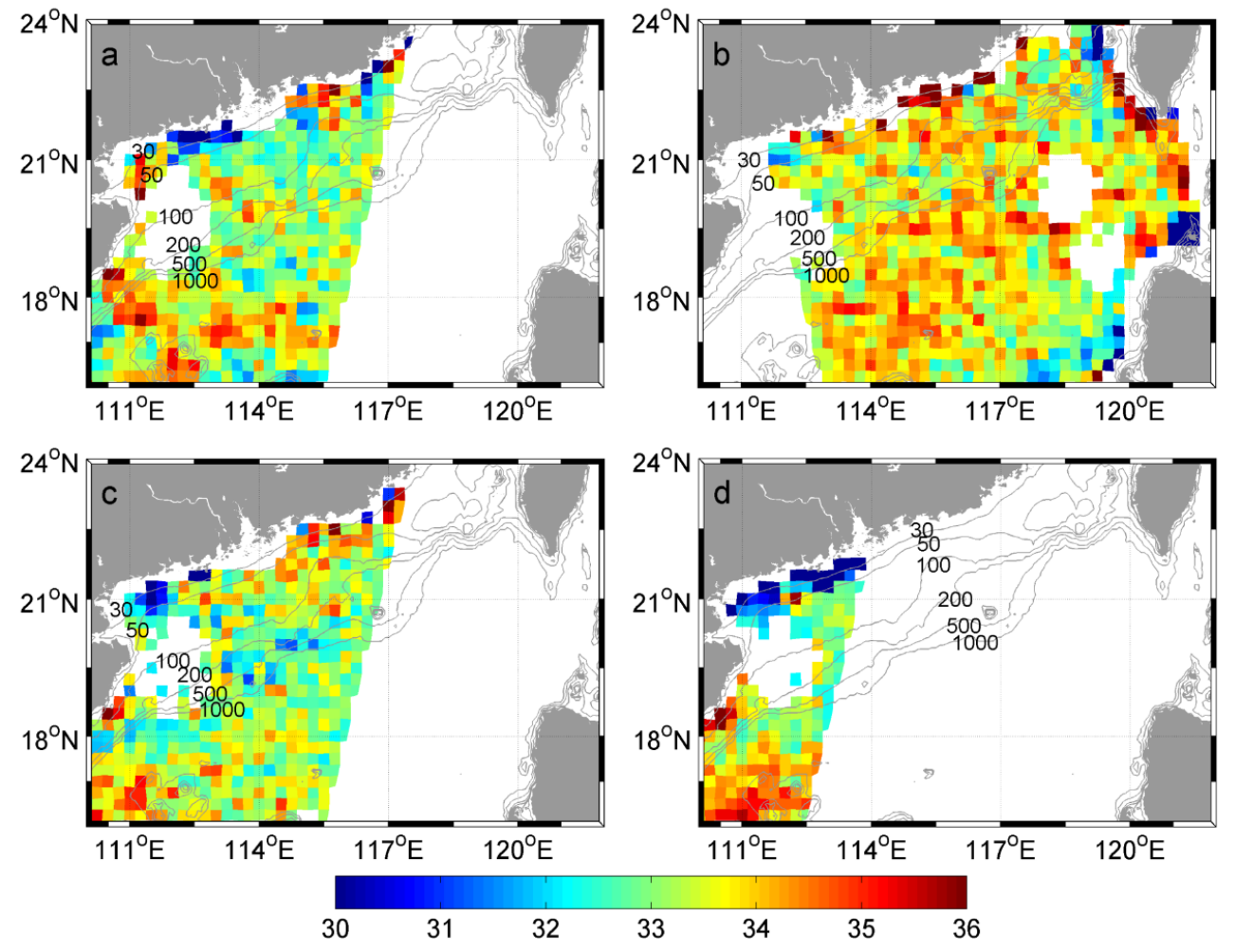

Figure 6. Sea surface salinity (SSS) distribution images in the NSCS on (a) 10, (b) 17, (c) 18, and (d) 21 September 2018. Color codes are in practical salinity units (PSU). Numerals on isobaths are in $\mathrm{m}$. 
Figure $6 \mathrm{c}$ shows a low salinity water plume, with the SSS lower than 30 and a length of about $150 \mathrm{~km}$, distributed in the west of the Pearl River Mouth on 18 September. On the other hand, Figure $4 \mathrm{~b}$ shows high concentration TSS water of a mean concentration higher than $15 \mathrm{mg} / \mathrm{L}$ distributed in the same area. A combination of above two observations reveals that the low salinity and high TSS water plume was originating from the Pearl River runoff, which contains rich terrigenous nutrients. However, the Chl-a bloom did not happen concurrently with high concentration nutrient inputs, instead, it was delayed, reaching a maximum of $40.0 \mathrm{mg} / \mathrm{m}^{3}$ on 21 September, about five days after typhoon landfall. Pan et al. [32] also found a similar Chl-a bloom delay phenomenon by numerical modeling.

To explain the mechanisms for the Chl-a bloom delay phenomenon, we propose the following scenario. In the view of ocean primary productivity, as chlorophyll carriers, phytoplankton blooms rely on two key conditions: nutrient concentration increase and underwater sunlight radiance intensification. During typhoon landfall, heavy rainfall causes the rivers to discharge a sharply increased quantity of sediments into the offshore water. The effects of terrigenous sediments on the marine ecologic environment are twofold: (1) raising the nutrient supply level, and (2) increasing the turbidity of seawater. Point one is favorable for phytoplankton blooms, while point two restrains the phytoplankton bloom by the attenuation of sunlight radiance in seawater. In addition, heavy cloudiness and heavy rain attenuate the sunlight incident on the sea surface. Thus, the phytoplankton bloom must delay for a couple of days until the TSS redeposits to a favorable level.

Figure 7 shows a curve of the Chl-a concentration vs. TSS concentration in the offshore subarea from 18 to 23 September 2018, after typhoon landfall on the coast near the Pearl River Estuary on 16 September. One can see that the TSS concentrations favorable for Chl-a bloom range from 6 to $7 \mathrm{mg} / \mathrm{L}$ in the study case.

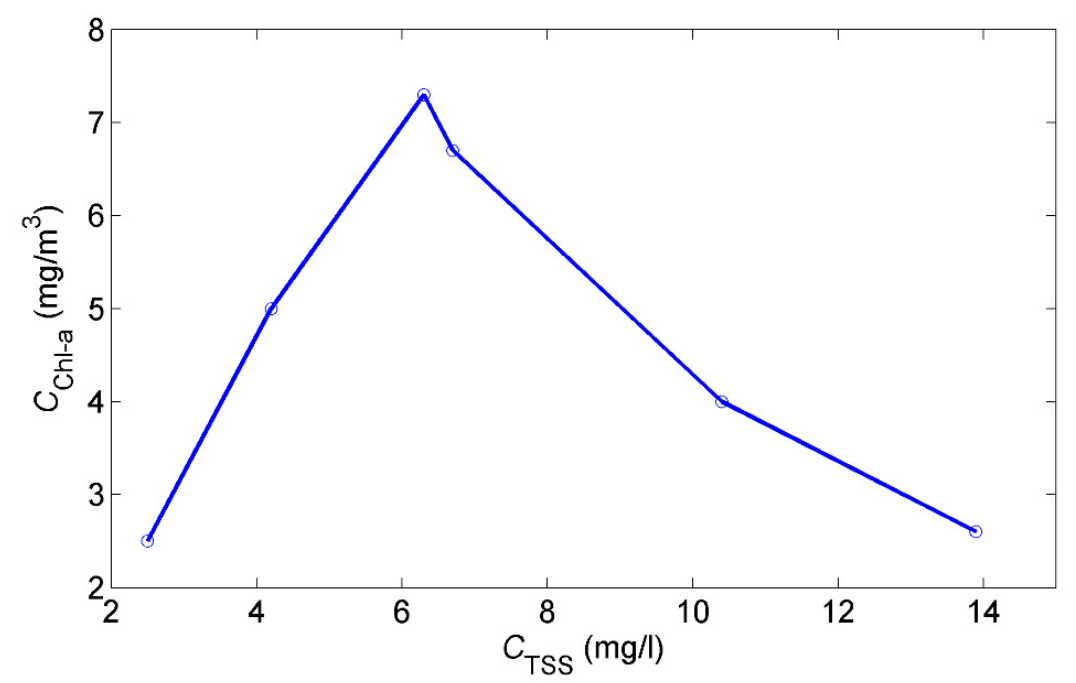

Figure 7. Chl-a concentration vs. TSS concentration in the offshore area from 18 to 23 September 2018, after typhoon Mangkhut (2018) landfall on the coast near the Pearl River Estuary on 16 September.

Figure 8 shows the time series of SLA derived from tidal gauge data measured at coastal stations in September 2018. At station Shenzhen, the SLA reached $2.5 \mathrm{~m}$ at 4:00 UTC, $5 \mathrm{~h}$ before typhoon landfall on 16 September (no data after that). At station Hong Kong, the SLA showed a maximum surge of $1.91 \mathrm{~m}$ at 7:00 UTC, $2 \mathrm{~h}$ before typhoon landfall on 16 September. Station Zhapo, which is located in the south of the typhoon track, showed a surge of $1.17 \mathrm{~m}$ at 9:00 UTC, just the time for typhoon landfall. The time lags of the SLA at the three stations imply that there was a typhoon-forced solitary continental shelf wave propagating southwestward along the coastline [33]. The waves carrying low salinity and high TSS concentration water discharged from the Pearl River spread southwestward along the coast. 


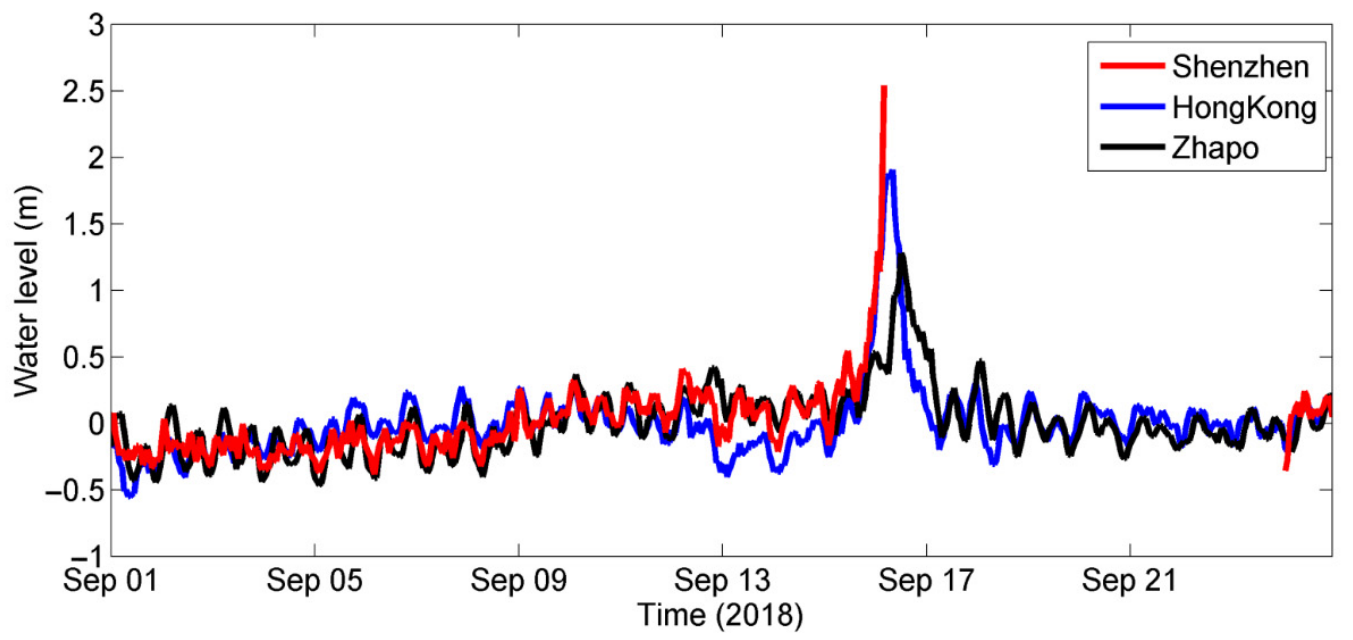

Figure 8. SLA time series at tidal gauge stations Shenzhen (red curve), Hong Kong (blue curve), and Zhapo (black curve) in September 2018.

\subsection{Shelf Area}

Figure 9 shows time series images of SST and sea surface wind, as well as latitudinal distributions of the along-track SWH in the NSCS after typhoon Mangkhut (2018) passage on 16, 17, and 18 September 2018. One can see a remarkable SST cooling event (about 3 to $5{ }^{\circ} \mathrm{C}$ ) along the typhoon track. In the shelf area, the wind speed was over $30 \mathrm{~m} / \mathrm{s}$ during typhoon passage, and decreased to lower than $10 \mathrm{~m} / \mathrm{s}$ after typhoon landfall. However, the highly variable wind directions were not favorable for the seaward Ekman transport. Meanwhile, the sea state was coming down from the $\mathrm{SWH}$, from greater than $11 \mathrm{~m}$ to about $2 \mathrm{~m}$.

Figure 10d-f shows the Ekman pumping velocity on 15, 16, and 18 September 2018, respectively. One can see that the upwelling on 15 September was weak (about $0.3 \times 10^{-6} \mathrm{~m} / \mathrm{s}$ ) on the continental shelf of the NSCS. On 16 September, when typhoon Mangkhut (2018) reached the shelf area, the upwelling was apparently stronger. The velocity of the upwelling was as high as $8 \times 10^{-6} \mathrm{~m} / \mathrm{s}$, which increased about twenty times, similar to the results from mooring observation analysis for typhoon Washi (2005) [34]. Three days after typhoon passage, the Ekman pumping velocity returned to the same level as 15 September in the shelf area. We can also see that the velocity was negative (i.e., downwelling) in the left side of the typhoon track, which should be the reason that SST dropped in the right side of the typhoon track, and was much larger than that in the left side [35].

Figure $5 \mathrm{~b}$ shows that the concentration of Chl-a increased three times from $0.2 \mathrm{mg} / \mathrm{m}^{3}$ on 15 September, before typhoon landfall, to $0.6 \mathrm{mg} / \mathrm{m}^{3}$ on 18 September, only two days after typhoon landfall, and sustained a level higher than $1.0 \mathrm{mg} / \mathrm{m}^{3}$ for four days. Thus, it is reasonable to attribute this immediate Chl-a bloom to the direct response of the shelf area to typhoon passage. The vertical mixing enhanced by the sea surface waves, with the SWH as high as $11 \mathrm{~m}$ and upwelling induced by typhoon pumping, brought the phytoplankton in the subsurface layer up to the surface layer within a short time, and maintained the Chl-a bloom for four days [36]. The direct injection of TSS transported by the strong winds, together with sea spray aerosols into the atmosphere through breaking waves during whitecap formation, should be accounted for such a significant resuspension of sea floor sediment $[10,11]$. Concurrently, the TSS concentration increased by 3.3 times, from $0.8 \mathrm{mg} / \mathrm{L}$ to $2.5 \mathrm{mg} / \mathrm{L}$, as shown in Figure 5b, and high SSS water with a salinity of $34-35$ occupied the major study area, as shown in Figure 6b, providing additional evidence for the above interpretation. 

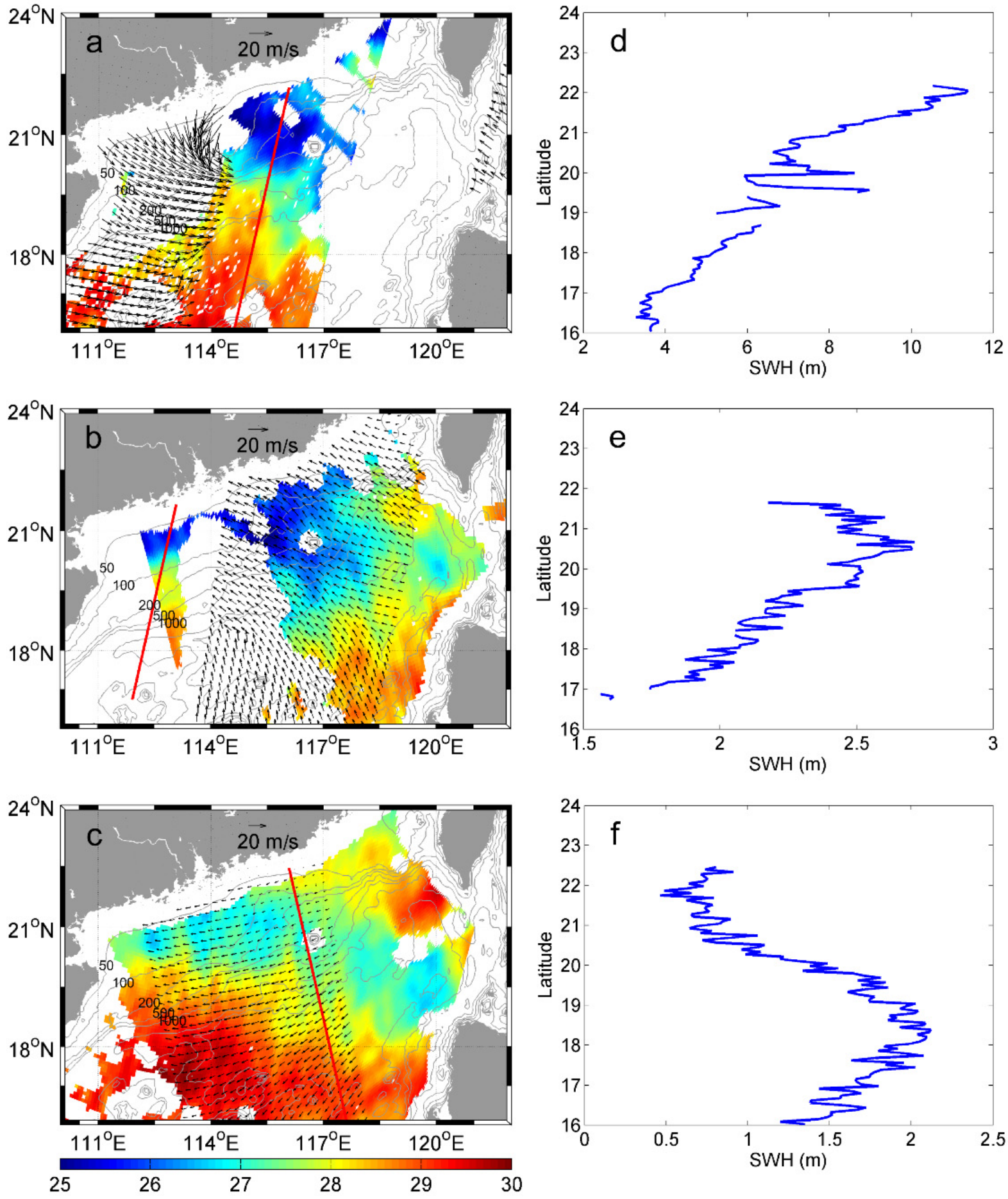

Figure 9. (a-c) Time series images of SST (color codes) and sea surface wind (arrows) in the NSCS on 16, 17, and 18 September 2018. Red lines represent satellite altimeter tracks in (a) Sentinel 3a, passed over at 2:29 UTC on 16 September, (b) Saral-AltiKa, passed over at 10:39 UTC on 17 September, and (c) Sentinel 3a, passed over at 13:59 UTC on 19 September. Color codes of SST are in degrees Celsius. Numerals on isobaths are in $\mathbf{m}$. (d-f) Latitudinal distributions of the along-track SWH. 

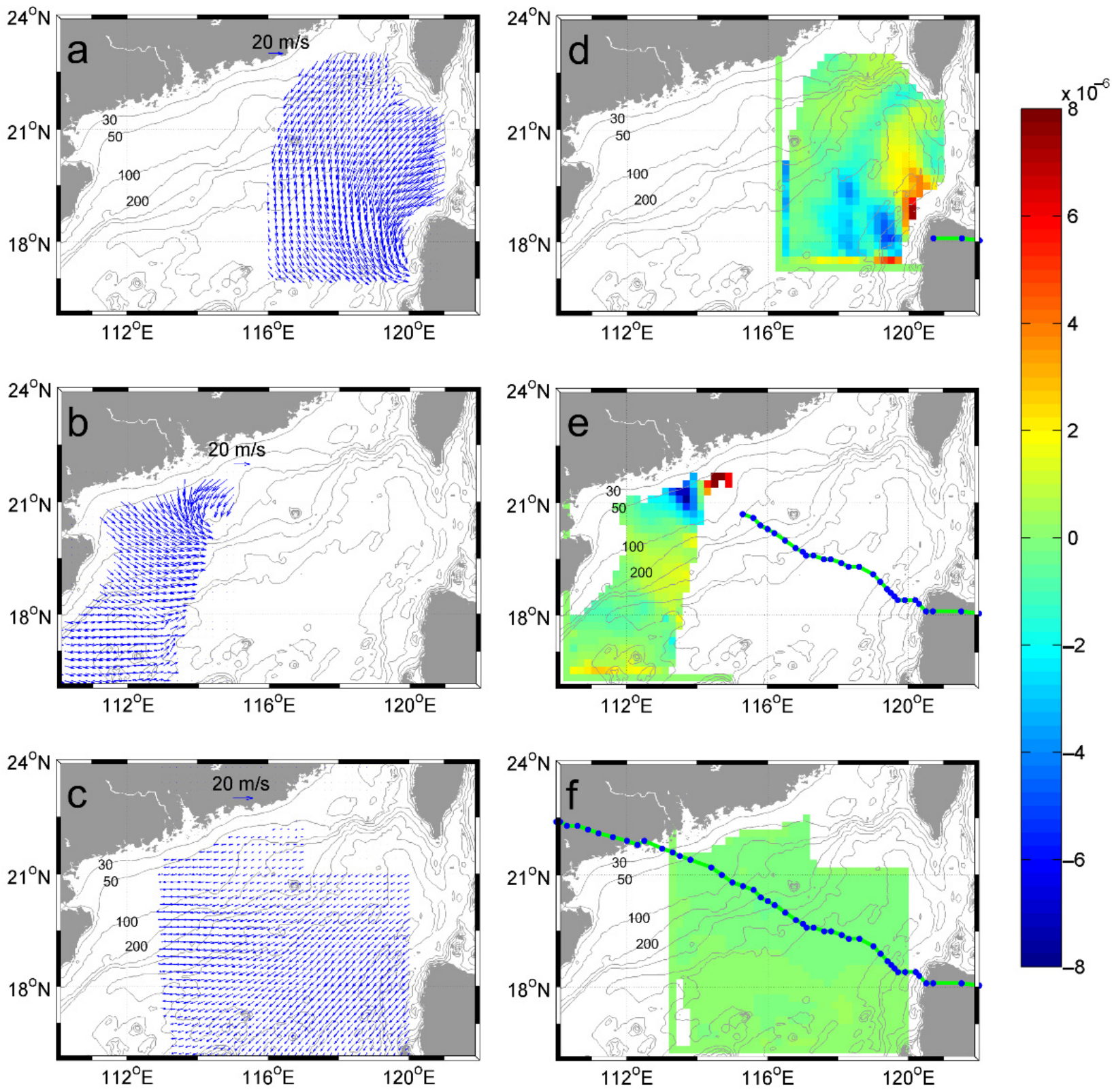

Figure 10. (a-c) Sea surface wind (arrows) in the NSCS on 15, 16, and 18 September 2018. (d-f) Ekman pumping velocity on 15,16 , and 18 September 2018. The unit of velocity is $\mathrm{m} / \mathrm{s}$. The green curve with blue dots (every $3 \mathrm{~h}$ ) represents the typhoon track. Numerals on isobaths are in $\mathrm{m}$.

\subsection{Basin Area}

In the basin area, the Chl-a concentration was $0.1 \mathrm{mg} / \mathrm{m}^{3}$ on 15 September, before typhoon Mangkhut (2018) passage, and increased to $0.2 \mathrm{mg} / \mathrm{m}^{3}$ after typhoon passage, against the $0.1 \mathrm{mg} / \mathrm{m}^{3}$ monthly mean Chl-a concentration in September from 2002 to 2016. Therefore, the passage of typhoon Mangkhut (2018) induced an increase in the Chl-a concentration in the basin area that was twice the monthly mean value.

Figure 11 shows the temperature and salinity profiles measured by the Argo float in the west of Luzon Strait on 9, 13, 17, and 21 September 2018. The four vertical distribution profiles of the water temperature and salinity were measured within $21 \mathrm{~km}$. One can see that the temperature (salinity) at a pressure less than $40 \mathrm{dbar}(\sim \mathrm{depth}<40 \mathrm{~m})$ was almost homogeneous at $28.8^{\circ} \mathrm{C}$ (33.1) on 9 and 13 September. At the deeper layer, the temperature decreased with the depth. After the typhoon passed $20 \mathrm{~km}$ away from point A at 12:00 UTC 
on 15 September, the temperature dropped from $28.8^{\circ} \mathrm{C}$ to $26.9^{\circ} \mathrm{C}$ on 17 September, and the salinity increased from 33.1 to 33.8 . On 21 September, the temperature increased to $27.4^{\circ} \mathrm{C}$. During the period of typhoon passage, the depth of the mixed layer was deepened from the original $40 \mathrm{~m}$ to $80 \mathrm{~m}$.

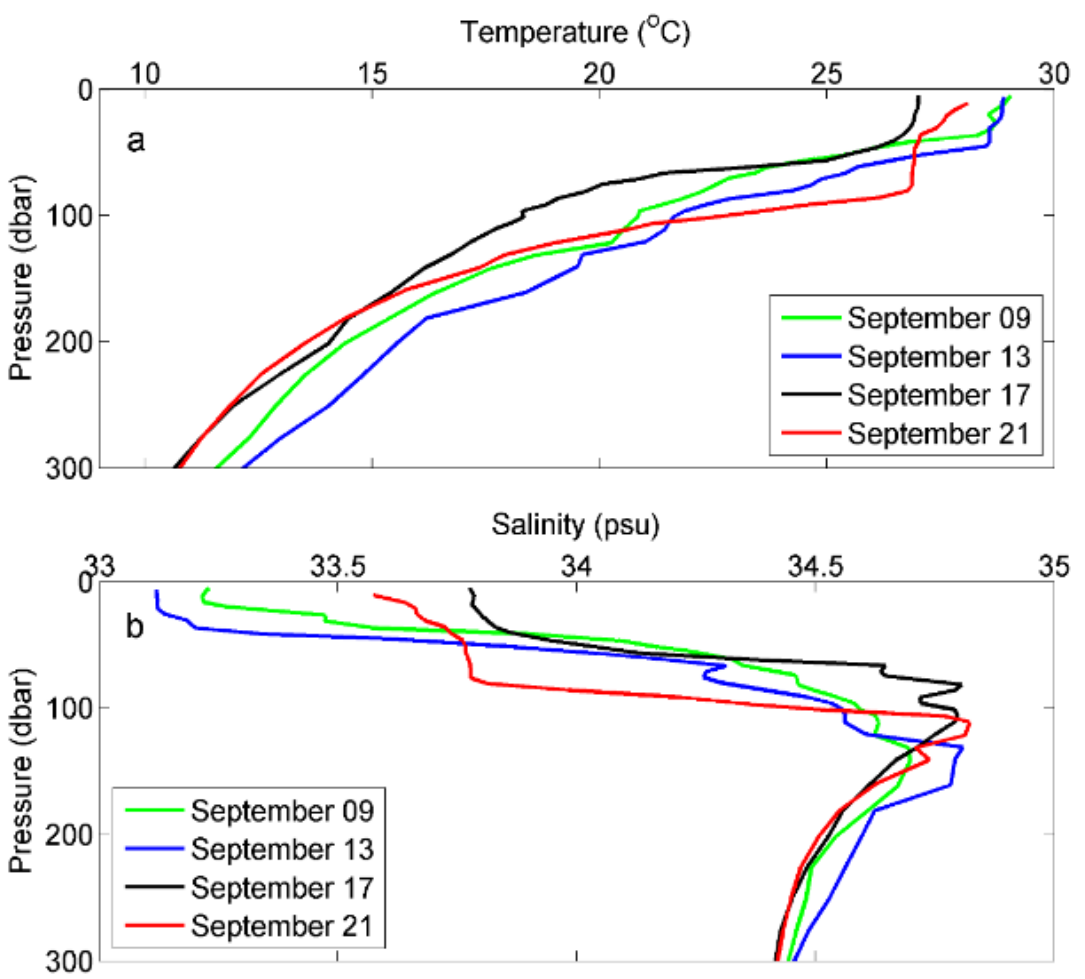

Figure 11. (a)Temperature and (b) salinity profiles measured by the Argo float in the basin area on 9 , 13, 17, and 21 September 2018.

Zhao et al. [37] showed that the Chl-a concentration west of the Luzon Strait was low in all seasons, except winter. Chen et al. [3] attributed the enhancement of the Chl-a concentration to the strong vertical mixing and upwelling during a typhoon process in this area. From Figure 11, one can see that, in this case, the mixed layer depth was deepened by $40 \mathrm{~m}$. It is reasonable to attribute the phytoplankton bloom to the nutrient supply brought up by the vertical mixing and upwelling [36]. On the other hand, the observation results showed that the maximum Chl-a concentration existed in the subsurface water at depths of 50-70 $\mathrm{m} \mathrm{[38-40].} \mathrm{It} \mathrm{is} \mathrm{strong} \mathrm{vertical} \mathrm{mixing} \mathrm{that} \mathrm{transports} \mathrm{the} \mathrm{phytoplankton} \mathrm{in} \mathrm{the}$ subsurface layer up to the surface layer, and causes the Chl-a concentration to increase.

Like the case observed in the shelf area, the Chl-a concentration in the basin area increased immediately after typhoon Mangkhut (2018) passed, then decreased gradually, implying that the nutrient supply by typhoon-induced vertical mixing and upwelling was gradually consumed. Thus, the observed Chl-a bloom in the basin area was a transient event in response to the passage of typhoon Mangkhut (2018).

\section{Conclusions}

This study investigates the behavior of spatiotemporal distributions of ocean color elements, including the TSS and the Chl-a, in response to tropical cyclones. The case of typhoon Mangkhut (2018) passing over the NSCS on 16 September 2018 is examined using satellite multi-sensor observations, Argo float profiles, and tidal gauge sea level data. The major findings and results are summarized as follows.

Typhoon Mangkhut (2018) resulted in transient events of TSS concentration peaks and Chl-a blooms, with the spatial distribution and timing behavior different in the offshore, shelf, and basin areas. In the offshore area from the coast to isobath $50 \mathrm{~m}$, the mean TSS 
concentration reached $13.9 \mathrm{mg} / \mathrm{L}$ on 18 September 2018, two days after typhoon landfall, against about $3.5 \mathrm{mg} / \mathrm{L}$ before typhoon landfall. In the shelf area with depths from $50 \mathrm{~m}$ to $100 \mathrm{~m}$, the mean TSS concentration reached $2.5 \mathrm{mg} / \mathrm{L}$, against about $1 \mathrm{mg} / \mathrm{L}$ before typhoon landfall. In the basin area, the mean TSS concentration had only a little fluctuation. On the other hand, in the offshore area, the mean Chl-a concentration reached $7.3 \mathrm{mg} / \mathrm{m}^{3}$ on 21 September, five days after typhoon landfall, against the $2.4 \mathrm{mg} / \mathrm{m}^{3}$ monthly mean value. In the shelf area, the mean Chl-a concentration increased from $0.2 \mathrm{mg} / \mathrm{m}^{3}$ to $0.6 \mathrm{mg} / \mathrm{m}^{3}$ in two days, implying a direct response to vertical mixing and upwelling enhanced by the typhoon. In the basin area, the Chl-a concentration increased from $0.1 \mathrm{mg} / \mathrm{m}^{3}$ to $0.2 \mathrm{mg} / \mathrm{m}^{3}$ during typhoon passage.

Concurrent dynamic conditions, including SST, SSS, SLA, SWH, wind fields, water depth, Argo float temperature, and salinity profiles are analyzed for exploration of spatiotemporal distribution features of the TSS and the Chl-a, as well as the timing lags between their peaks and blooms. The results indicate that, in the offshore area, typhooninduced solitary continental waves may play a dominant role in determining the spatial distribution features of the TSS originating from the heavy loaded Pearl River runoff. The Chl-a bloom was delayed rather than concurrent occurring with the terrigenous nutrient peak, attributed to the nonlinear relation between the Chl-a concentration and the TSS concentration. In the shelf and basin areas, typhoon-induced vertical mixing and upwelling may play dominant roles in determining the spatiotemporal behavior of the TSS and the Chl-a. Furthermore, the direct injection of the particulate matter from land transported by strong wind should be a possible mechanism for the TSS increase in the shelf area.

Author Contributions: All authors have made significant contributions to this research. J.L. and Q.L. analyzed the data; L.X. and M.L. provided important insights and suggestions on this research; J.L. and Q.Z. wrote the paper. All authors have read and agreed to the published version of the manuscript.

Funding: Supported by National Natural Science Foundation of China (41706025, 41776034, 41506018), Innovation Team Plan for Universities in Guangdong Province (2019KCXTF021), Matched Grant of Guangdong Ocean University (P15299), Open Fund of the Key Laboratory of Ocean Circulation and Waves, Chinese Academy of Sciences, Program for Scientific Research Start-up Funds of Guangdong Ocean University, Guangdong Province First-Class Discipline Plan (CYL231419012).

Data Availability Statement: The typhoon data are obtained from the Tropical Cyclone Data Center of the China Meteorological Administration (CMA) (http://tcdata.typhoon.org.cn). The Chl-a concentration, sea surface wind and sea surface salinity (SSS) data are downloaded from http: / / oceandata.sci.gsfc.nasa.gov/. The sea surface temperature (SST) data are downloaded from https:// podaac-opendap.jpl.nasa.gov/.

Acknowledgments: The authors are grateful to the anonymous reviewers for their valuable suggestions and comments.

Conflicts of Interest: The researchers claim no conflict of interest.

\section{References}

1. Yue, X.; Zhang, B.; Liu, G.; Li, X.; He, Y.; Zhang, H. Upper Ocean Response to Typhoon Kalmaegi and Sarika in the South China Sea from Multiple-Satellite Observations and Numerical Simulations. Remote Sens. 2018, 10, 348. [CrossRef]

2. Pan, J.; Huang, L.; Devlin, A.; Lin, H. Quantification of Typhoon-Induced Phytoplankton Blooms Using Satellite Multi-Sensor Data. Remote Sens. 2018, 10, 318. [CrossRef]

3. Chen, X.; Pan, D.; He, X.; Bai, Y.; Wang, D. Upper ocean responses to category 5 typhoon Megi in the western north Pacific. Acta Oceanol. Sin. 2012, 31, 51-58. [CrossRef]

4. Lu, Z.; Wang, G.; Shang, X. Response of a Preexisting Cyclonic Ocean Eddy to a Typhoon. J. Phys. Oceanogr. 2016, 46. [CrossRef]

5. Palanques, A.; Guillén, J.; Puig, P.; Madron, X.D.D. Storm-driven shelf-to-canyon suspended sediment transport at the southwestern Gulf of Lions. Cont. Shelf Res. 2008, 28, 1947-1956. [CrossRef]

6. Qiao, L.; Wang, Z.; Liu, S.; Li, G.; Liu, X.; Huang, L.; Xue, W.; Zhong, Y. From continental shelf seas to the western Pacific: The path and mechanism of cross-shelf suspended sediment transport in the Yellow Sea and East China Sea. Earth Sci. Front. 2017, 24, 134-140.

7. Wang, D.; Mooers, C. Coastal-trapped waves in a continuously stratified ocean. J. Phys. Oceanogr. 1976, 6, 853-863. [CrossRef] 
8. Chen, N.; Han, G.; Yang, J.; Chen, D. Hurricane sandy storm surges observed by hy-2a satellite altimetry and tide gauges. J. Geophys. Res. Ocean. 2014, 119, 4542-4548. [CrossRef]

9. Weber, J.; Drivdal, M. Radiation stress and mean drift in continental shelf waves. Cont. Shelf Res. 2012, 35, 108-116. [CrossRef]

10. Lewis, E.; Schwartz, S. Sea Salt Aerosol Production: Mechanisms, Methods, Measurements, and Models-A Critical Review; AGU: Washington, DC, USA, 2004; Volume 152, pp. 119-179.

11. Benzekry, S.; Barbolosi, D.; Benabdallah, A.; Hubert, F.; Hahnfeldt, P. Sea-salt aerosol mass concentration oscillations after rainfall, derived from long-term measurements in lampedusa (central mediterranean). ISRN Meteorol. 2012, 4, 1-8.

12. Li, X.; Zhang, X.; Fu, D. Strengthening effect of super typhoon rammasun (2014) on upwelling and cold eddies in the South China Sea. J. Ocean. Limnol. 2021. [CrossRef]

13. Wang, G.; Su, J.; Ding, Y.; Chen, D. Tropical cyclone genesis over the South China Sea. J. Mar. Syst. 2007, 68, 318-326. [CrossRef]

14. Shang, S.; Li, L.; Sun, F.; Wu, J.; Hu, C.; Chen, D.; Ning, X.; Qiu, Y.; Zhang, C.; Shang, S. Changes of temperature and bio-optical properties in the South China Sea in response to Typhoon Lingling, 2001. Geophys. Res. Lett. 2008, 35, L10602. [CrossRef]

15. Zheng, Q.; Fang, G.F.; Song, Y.T. Introduction to special section: Dynamics and Circulation of the Yellow, East, and South China Seas. J. Geophys. Res. Ocean. 2006, 111. [CrossRef]

16. Ying, M.; Zhang, W.; Yu, H.; Lu, X.; Feng, J.; Fan, Y.; Zhu, Y.; Chen, D. An Overview of the China Meteorological Administration Tropical Cyclone Database. J. Atmos. Ocean. Technol. 2014, 31, 287-301. [CrossRef]

17. Hu, C.; Lee, Z.; Franz, B. Chlorophyll aalgorithms for oligotrophic oceans: A novel approach based on three-band reflectance difference. J. Geophys. Res. Ocean. 2011, 117. [CrossRef]

18. Kahru, M.; Kudela, R.M.; Manzano-Sarabia, M.; Mitchell, B.G. Trends in the surface chlorophyll of the California Current: Merging data from multiple ocean color satellites. Deep Sea Res. Part II Top. Stud. Oceanogr. 2012, 77-80, 89-98. [CrossRef]

19. Li, X.; Zhang, L.; Tian, L.; Wang, X.; Liu, J. Merging chlorophyll-a data from multiple ocean color sensors in South China Sea. J. Remote Sens. 2014, 19, 680-689.

20. Iwasaki, S. Daily Variation of chlorophyll-a Concentration Increased by Typhoon Activity. Remote Sens. 2020, 12, 1259. [CrossRef]

21. Meissner, T.; Wentz, F.J.; Manaster, A.; Lindsley, R. Remote Sensing Systems SMAP Ocean Surface Salinities [Level 2C, Level 3 Running 8-Day, Level 3 Monthly], Version 4.0 Validated Release; Remote Sensing Systems: Santa Rosa, CA, USA, 2019.

22. Verron, J.; Sengenes, P.; Lambin, J.; Noubel, J.; Steunou, N.; Guillot, A.; Picot, N.; Coutin-Faye, S.; Sharma, R.; Gairola, R.M.; et al. The SARAL/AltiKa Altimetry Satellite Mission. Mar. Geod. 2015, 38, 2-21. [CrossRef]

23. Miller, R.; Mckee, B. Using modis terra $250 \mathrm{~m}$ imagery to map concentrations of total suspended matter in coastal waters. Remote Sens. Environ. 2004, 93, 259-266. [CrossRef]

24. Zhang, M.; Tang, J.; Dong, Q.; Song, Q.T.; Ding, J. Retrieval of total suspended matter concentration in the Yellow and East China Seas from MODIS imagery. Remote Sens. Environ. 2010, 2, 392-403. [CrossRef]

25. Tassan, S. An improved in-water algorithm for the determination of chlorophyll and suspended sediment concentration from Thematic Mapper data in coastal waters. Int. J. Remote Sens. 1993, 6, 1221-1229. [CrossRef]

26. Pan, D.; Huang, H.; Mao, T.; Mao, Z. Ocean color remote sensing by SeaWiFS in China. In Proceedings of the 20th Asian Conference on Remote Sensing, Hong Kong, China, 22-25 November 1999.

27. Enriquez, A.; Friehe, C. Effects of wind stress and wind stress curl variability on coastal upwelling. J. Phys. Oceanogr. 1995, 7, 1651-1671. [CrossRef]

28. Hellerman, S.; Rosenstein, M. Normal monthly wind stress over the world ocean with error estimates. J. Phys. Oceanogr. 1983, 13, 1093-1104. [CrossRef]

29. Wang, X.; Jiang, W.; Deng, Y.; Jiang, Z. Hourly Rainfall Dynamics and Hazard Dynamic Assessment of Mangkhut (2018) Typhoon-affected Areas. J. Catastrophol. 2019, 34, 202-208, (In Chinese with English abstract).

30. David, B.P.; Thomas, S.; Vittorio, B.; Stefan, M.; Arnold, D.; Stuart, P. ESA-MERIS 10-Year Mission Reveals Contrasting Phytoplankton Bloom Dynamics in Two Tropical Regions of Northern Australia. Remote Sens. 2014, 6, $2963-2988$.

31. Liu, H.; Hu, Z.; Huang, L.; Huang, H.; Chen, Z.; Song, X.; Ke, Z.; Zhou, L. Biological response to typhoon in northern South China Sea: A case study of "Koppu". Cont. Shelf Res. 2013, 68, 123-132. [CrossRef]

32. Pan, G.; Chai, F.; Tang, D.; Wang, D. Marine phytoplankton biomass responses to typhoon events in the South China Sea based on physical-biogeochemical model. Ecol. Model. 2017, 356, 38-47. [CrossRef]

33. Zheng, Q.; Zhu, B.; Li, J.; Sun, Z.; Xu, Y.; Hu, J. Growth and dissipation of typhoon-forced solitary continental shelf waves in the northern South China Sea. Clim. Dynam. 2015, 3-4, 1-13. [CrossRef]

34. Wang, L.; Xie, L.; Zheng, Q.; Li, J.; Li, M.; Hou, Y. Tropical cyclone enhanced vertical transport in the northwestern South China Sea I: Mooring observation analysis for Washi (2005). Estuar. Coast Shelf S. 2020, 235, 106599. [CrossRef]

35. Shi, Y.; Xie, L.; Li, M.; Wang, L.; Zheng, M.; Shen, Y. Impacts of typhoon Mujigea on sea surface temperature and chlorophyll-a concentration in the coastal ocean of western Guangdong. J. Guangdong Ocean Univ. 2017, 3, 49-58, (In Chinese with English abstract).

36. Shi, W.; Wang, M. Observations of a Hurricane Katrina-induced phytoplankton bloom in the Gulf of Mexico. Geophys. Res. Lett. 2007, 34, 93-104. [CrossRef]

37. Zhao, H.; Qi, Y.Q.; Wang, D.X. Study on the features of chlorophyll-a derived from SeaWiFS in the South China Sea. Acta Oceanol. Sin. 2005, 27, 45-52. 
38. Gao, S.; Wang, H.; Liu, G.; Huang, L. The statistical estimation of the vertical distribution of chlorophyll a concentration in the South China Sea. Acta Oceanol. Sin. 2010, 5, 13-26.

39. Liao, X.; Dai, M.; Gong, X.; Liu, H.; Huang, H. Subsurface chlorophyll a maximum and its possible causes in the southern South China Sea. J. Trop. Oceanogr. 2018, 37, 45-56. [CrossRef]

40. Ravichandran, M.; Girishkumar, M.S.; Riser, S. Observed variability of chrolophyll-a using Argo profiling floats in the southeastern Arabian Sea. Deep Sea Res. Part I Oceanogr. Res. Pap. 2012, 65, 15-25. [CrossRef] 